\title{
Avifaunal Diversity and Water Quality Analysis of Urban Wetlands of Colombo, Sri Lanka
}

T.I.K. Munaweera ${ }^{1}$ and K.V.S.N. Bandara ${ }^{2 *}$

\section{${ }^{1}$ Department of Plant Sciences, \\ Faculty of Agriculture, Rajarata University of Sri Lanka, \\ Anuradhapura, Sri Lanka. \\ ${ }^{2}$ Department of Zoology Faculty of Science, University of Ruhuna, Matara, Sri Lanka. \\ Correspondence: \\ *kvsandun@zoo.ruh.ac.lk \\ (iD) https://orcid.org/0000-0003-1243-0860}

DOI: http://doi.org/10.4038/sljae.v3i1.65

\begin{abstract}
The present study was carried out to determine the effect of water quality on the diversity and distribution of avifauna in urban wetlands. The bird aggregation and physical and chemical parameters of water bodies were assessed using standard field-based methods. The study recorded 67 bird species of 35 families. The bird population parameters were influenced by total dissolved solids, dissolved oxygen, salinity, and visibility. The Shannon- Wiener species diversity index $\left(\mathrm{H}^{\prime}\right)$ ranged between $0.99 \pm 0.05-1.71 \pm 0.03$. The density of aquatic birds and species richness ranged between $1677.45 \pm 137.2$ - 4990.09 \pm 151.3 birdskm- ${ }^{2}$ and $14.85 \pm 0.36-22.07 \pm 0.68$ respectively in the five wetlands studied. ShannonWiener diversity index $\left(\mathrm{H}^{\prime}\right)$ resulted in significant negative relationships with total dissolved solids $\left(R^{2}=0.716 ; p<0.05\right)$, and salinity $\left(R^{2}=0.919 ; p<0.01\right)$. Bird density was positively related with Secchi disk depth $\left(R^{2}=0.457 ; p<0.05\right)$. Further, bird density negatively correlated with salinity $\left(R^{2}=0.568 ; p<0.05\right)$ and total dissolved solids $\left(\mathrm{BD}=-0.003 \mathrm{TDS}+3.903 ; R^{2}=0.566 ; p<0.05\right)$. The results of the principal component analysis indicated Secchi disk depth and dissolved oxygen were extremely influenced on Thalangama tank followed by Heen Ela marsh. For the wetland sites of Beddagana and Kiribathgoda, salinity and total dissolved solids were the extremely influential parameters, where Beddagana and Diyasaru Park had an influence from electrical conductivity on the variation of diversity, density, and species richness of the aquatic birds.
\end{abstract}

Keywords: Aquatic birds, Aquatic habitats, Bird assemblage, Physical and chemical parameters, Water pollution 


\section{Introduction}

A wetland can be defined as a transitional land between the terrestrial and aquatic ecosystem with a water table, which is at or near the land surface, covered by shallow water (Cherry 2011). The wetland environment is rich with an array of biodiversity in which water birds can be considered as an important component, occupying several trophic levels in the wetland nutrient cycles indicating a special cultural and social role in the local communities (Green 2014). Birds utilize wetlands as a habitat, mainly for nesting, roosting, breeding, feeding, shelter, resting, social interaction, and many other activities (Stewart 2007). Also, wetlands support congregation of a large number of migratory birds as it has high nutritional value and productivity (Paracuellos 2006). These birds use wetland habitats either throughout or during a certain part of their life and support to keep the ecological balance of this delicate ecosystem (Keten et al. 2020).

From an urban perspective, wetlands play a vital role in the assemblage and conservation of aquatic birds (Green 2014). In an urban environment, wetlands act as the last resort for many resident and migratory bird species (Murray et al. 2013). In local context, urban wetlands are highly prioritized for avifaunal conservation and to identify the international recognitions for wetland managements (https://www. ramsar.org). Among them, wetlands in Colombo are highly promising and recognized as critical areas for the conservation of biodiversity including a rich avifaunal population (Wetland management strategy 2016). Being one of the world's first wetland cities, Colombo is rich with clusters of wetlands and still, about $20 \mathrm{~km}^{2}$ of wetlands are located in the Colombo metropolitan area (Wetland management strategy 2016). These wetlands are providing vital habitats for more than 115 bird species including some rare migrants (Wetland management strategy 2016). Among them, several species are endemic and listed under threatened categories (Goonatilake 2020).

Colombo as the most commercialized city in Sri Lanka, these wetlands are alarmingly diminishing and subjected to pollution and reclamation events due to substantial development priorities and rapid population growth (Kotagama and Bambaradeniya 2006). These pollution sources directly alter the bio-physical condition of aquatic ecosystem and directly impair the natural water quality (Mitsch and Gossenlink 2000). The physical and chemical water parameters can be 
considered as major factors influencing the biotic components of the ecosystem including aquatic birds (Rameshkumar et al. 2016). The measurement of avifauna species becomes essential to evaluate the current status of a wetland ecosystem and also that demonstrates the wellbeing of specific wetland and can be considered an indicator species (Krebs 1999; Osborne 2000). Effects of water quality on aquatic bird diversity can be treated as the robustness of the wetland ecosystem and to established conservation priorities of aquatic birds in urban settings. Though there are many observations on annual bird migration and status of the resident bird population in Sri Lanka, no proper study has been conducted to reveal the threats on them. Hence, importance of this study is strongly justified as a baseline for the prospective studies and decision making. An attempt was made to evaluate the effect of water quality parameters on bird diversity in critical wetland clusters in Colombo and evaluate the ecological status. We propose the hypothesis that the impairment of water quality in urban wetlands is a direct influence on the diversity and distribution of aquatic bird species.

\section{Materials and Method}

\section{Study area}

The study was carried out in five urban wetlands in the Colombo and its suburbs of Sri Lanka (Fig. 1) viz. Beddagana Wetland Park (BG), Diyasaru Park (DS) situated at Thalawathugoda, Heen Ela marsh (HE) at Nawala, Kiribathgoda wetland area (KG) and Thalangama Tank (TL), ranging in size from 15- 25 ha (IUCN Sri Lanka and Central Environmental Authority (2006); Wetland management strategy 2016). The locations of these wetlands are highly urbanized and enclosed with human or commercial settlements. The annual mean minimum and maximum temperature varies around 26.5$29.5{ }^{\circ} \mathrm{C}$ and $2687 \mathrm{~mm}$ rainfall can be expected annually (http://en.climatedata.org). These wetlands are dominated by herb species, including the extensive active and abandoned paddy lands. Woodlands are also observable in the Colombo wetland complex. One third of all the studied wetlands are covered with tall and short herbs and open water habitats. Open water wetlands, such as tanks and canals cover represent just over $20 \%$ of all the wetlands (Wetland management strategy 2016). Variation of annual weather patterns and diversity of vegetation are the key factors of the bird aggregation of these wetland clusters in the study area. 


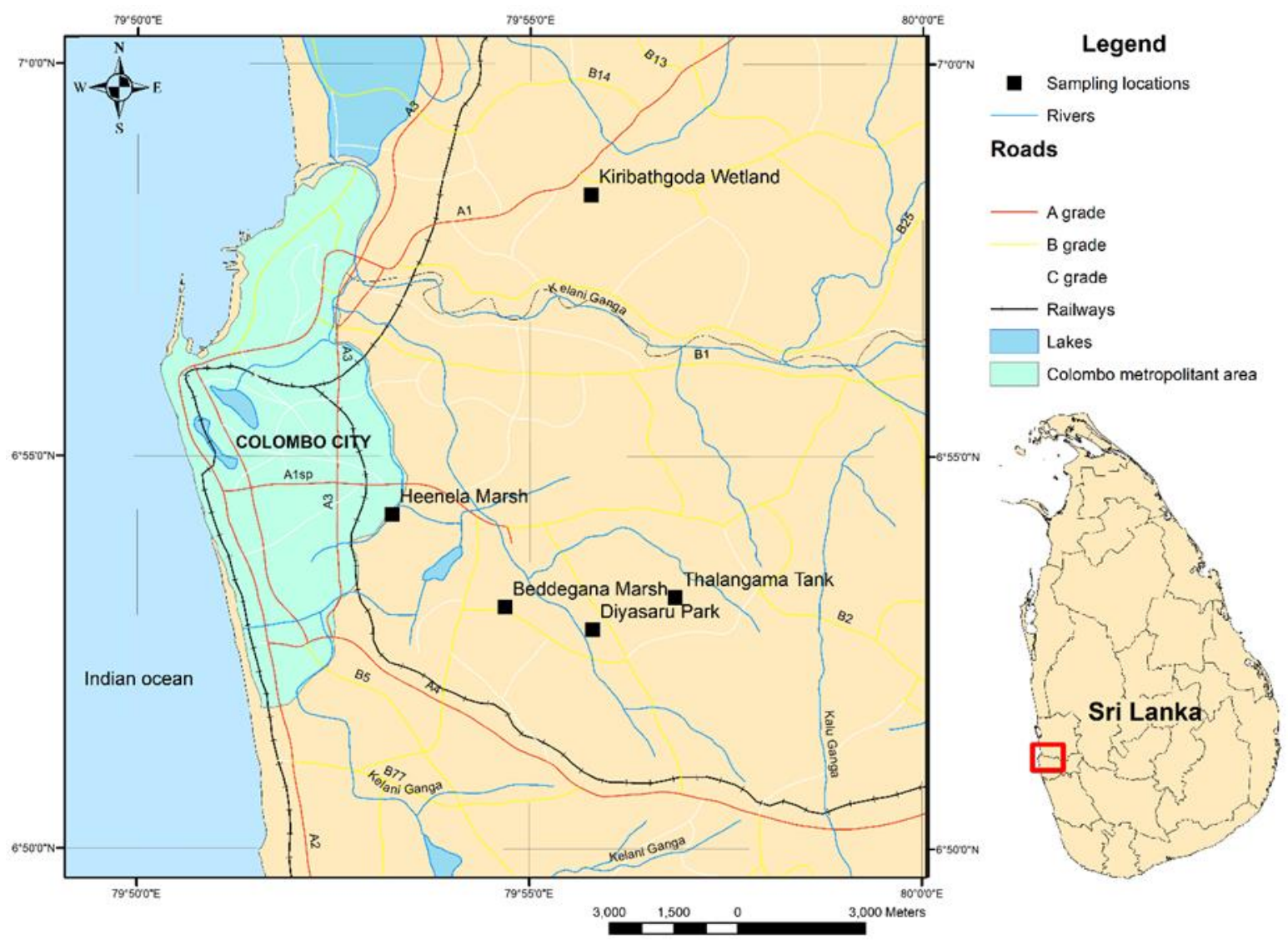

Figure 1. Geographic locations of the five urban wetlands studied in Colombo and suburbs. Inset shows the location of five studied wetlands relative to Colombo metropolitan area

\section{Field sampling}

This study was carried out from February 2018 to January 2019, visiting each wetland once a month. In the present study, the species diversity of wetland birds during migratory and non-migratory seasons was investigated. Four separate locations were selected in each wetland and point observations were made around 0600-0800 hrs with a binocular (Nikon Compact PROSTAFF) of $8 \times 42$ magnification with ten minutes observations in each point while rotating $360^{\circ}$ (Vijayan 1991; Bibby et al. 1992). Several species and individuals were counted in a $50 \mathrm{~m}$ radius. The birds were identified using standard field guides by Harrison and Worfolk (1999); Kotagama and Ratnavira (2017). Water quality data were taken per individual wetland in the selected locations. Three locations were selected in each site and water temperature (Tm), Total Dissolved Solids (TDS), pH, Dissolved Oxygen (DO), salinity, Electrical Conductivity (EC) were measured using previously calibrated HANNA HQ 40D multiparameter. To determine the visibility of the water, Secchi disk depth (SDD) was obtained. 


\section{Statistical analysis}

The recorded bird species were divided into two groups, as aquatic birds (water birds) and terrestrial birds. The Shannon Wiener index (Shannon and Weaver 1949), species richness (Krebs 1999), and the density (Rodger and Panwar 1990) of water birds were calculated for considering sole aquatic birds and considering both aquatic and terrestrial birds separately (results were not shown) observed in the wetlands. For the statistical analysis, the data of different locations in each wetland were pooled for the study period and average values and standard errors (SE) were calculated. Regression analysis was used to determine the relationship of each population parameter of aquatic birds (e.g. diversity, density, and richness) with few physical and chemical parameters of water. Bird count data were log transferred before the analysis. The correlation of overall bird population parameters (including terrestrial birds) with physical and chemical parameters was evaluated with Pearson correlation analysis. Principal component analysis (PCA) was used to define critical physical and chemical parameters for the variation of Shannon wiener index, species richness and the density of aquatic birds in each wetland studied. Prior to analyses, all variables were square root-transformed to better approximate the multi-normality. The statistical analysis was performed using MINITAB 14 (Maat 2015) and Primer V.5.2.2 software (Clarke and Warwick 2001).

\section{Results and discussion}

During the present study, 67 bird species were observed at five wetlands. Among them, 26 species were considered aquatic birds, and 04 species were migrant (Table 1). The distribution of the species was scattered through the five wetlands. However, several species (e.g., Porzana fusca and Pastor roseus) were only observed in particular habitats. A few of these species such as Oriental darter (Anhinga melanogaster) and Spot-billed pelican (Pelecanus philippensis) have special conservation status and considered as near threatened according to IUCN red list criteria (Goonatilake 2020). The highest aquatic bird diversity indicated by ShannonWiener species diversity index $\left(\mathrm{H}^{\prime}\right)$ was recorded in the Thalangama tank wetland (1.71 \pm 0.03$)$, while the lowest $(0.99 \pm 0.05)$ was recorded from Diyasaru Park (Fig. 2). The total bird density was maximum in Thalangama tank, with 4990.09 \pm 151.3 birdskm-2 ${ }^{2}$, and minimum in Heen Ela marsh with $1677.45 \pm 137.2$ birdskm-2 $^{2}$ (Fig. 2).

The species richness was also maximum in

Thalangama $(22.07 \pm 0.68)$ and minimum in 
Kiribathgoda wetland (14.85 \pm 0.36$)$ (Fig. 2).

Shannon- Wiener species diversity index $\left(\mathrm{H}^{\prime}\right)$, bird density, and species richness were highest in Thalangama Tank wetland. Those three population parameters in Thalangama Tank were significantly different across the other wetlands studied $(p<0.05)$.

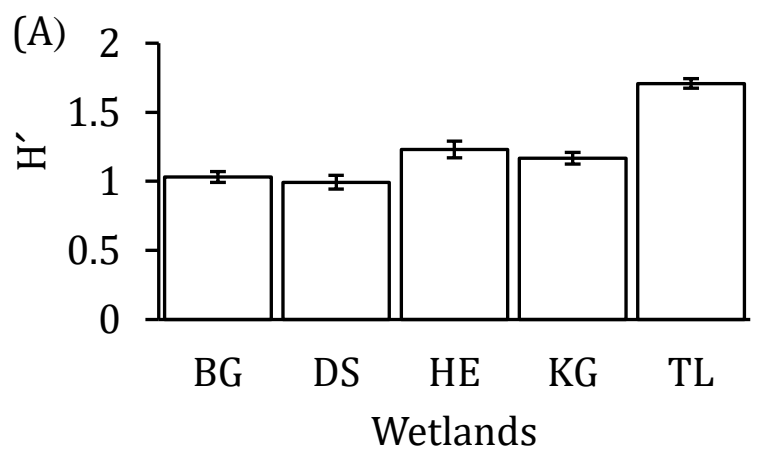

Shannon- Wiener species diversity index $\left(\mathrm{H}^{\prime}\right)$, bird density, species richness and water quality parameters in five wetlands are given in Table. 2 .
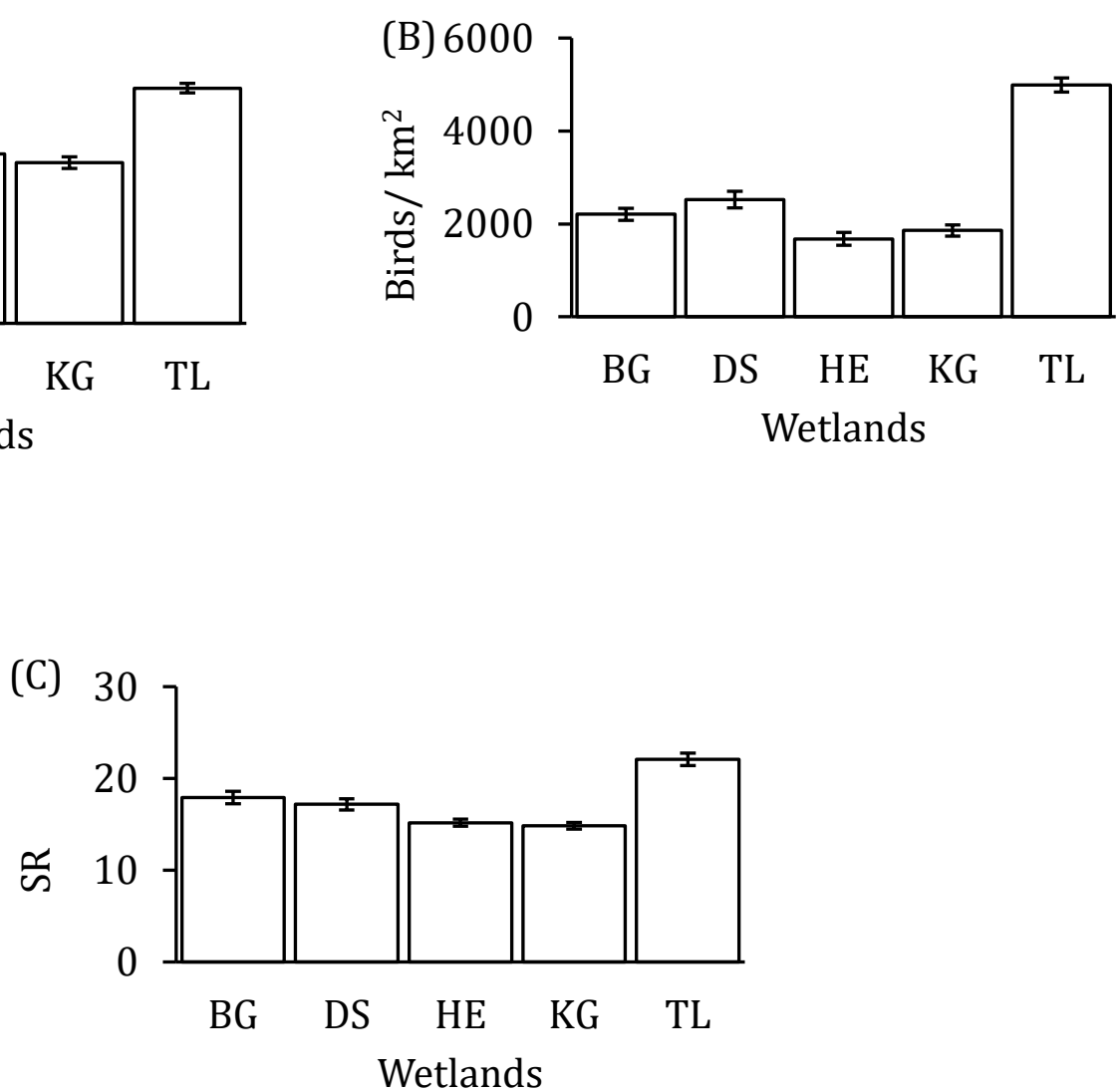

Figure 2. Variation of bird population parameters among the wetlands studied. (A) Shannon- Wiener species diversity index ( $\mathrm{H}^{\prime}$ ); (B) bird density (BD); (C) species richness (SR). Abbreviations of wetlands: Beddagana Wetland Park (BG), Diyasaru Park (DS), Heen Ela marsh (HE), Kiribathgoda wetland area (KG) and Thalangama Tank (TL). 
Table 1. Checklist of birds recorded during the study in five wetlands.

\begin{tabular}{|c|c|c|c|}
\hline Family & Scientific Name & Common Name & $\begin{array}{l}\text { National Conservation } \\
\text { Status (Goonatilake, } \\
2020 \text { ) }\end{array}$ \\
\hline \multirow[t]{3}{*}{ Accipitridae } & Spilornis cheela & Crested serpent-eagle & LC \\
\hline & Accipiter badius & Shikra & LC \\
\hline & Haliaeetus leucogaste & White-bellied sea eagle & $\mathrm{LC}$ \\
\hline \multirow[t]{4}{*}{ Alcedinidae } & Halcyon smyrnensis & White-throated kingfisher* & LC \\
\hline & Ceryle rudis & Pied kingfisher* & $\mathrm{LC}$ \\
\hline & Pelargopsis capensis & Stork billed kingfisher* & LC \\
\hline & Alcedo atthis & Common kingfisher* & $\mathrm{LC}$ \\
\hline \multirow[t]{2}{*}{ Aegithinidae } & Aegithina tiphia & Common iora & $\mathrm{LC}$ \\
\hline & Cypsiurus balasiensis & Asian palm-swift & $\mathrm{LC}$ \\
\hline Apodidae & Apus caffer & White-rumped swift & $\mathrm{LC}$ \\
\hline \multirow[t]{2}{*}{ Cisticolida } & Prinia inornata & Plain prinia & $\mathrm{LC}$ \\
\hline & Prinia sylvatica & Jungle prinia & LC \\
\hline Chloropseidae & Chloropsis jerdoni & Jerdon's leafbird & $\mathrm{LC}$ \\
\hline \multirow[t]{5}{*}{ Columbidae } & Ducula aenea & Green imperial-pigeon & $\mathrm{LC}$ \\
\hline & Chalcophaps indica & Emerald dove & LC \\
\hline & Stigmatopelia chinensis & Spotted dove & $\mathrm{LC}$ \\
\hline & Treron bicinctus & Orange-breasted green pigeon & LC \\
\hline & Columba livia & Rock pigeon & $\mathrm{LC}$ \\
\hline \multirow[t]{2}{*}{ Corvidae } & Corvus levaillantii & Jungle crow & LC \\
\hline & Corvus splendens & House crow & $\mathrm{LC}$ \\
\hline Cuculidae & Centropus sinensis & Greater coucal & $\mathrm{LC}$ \\
\hline Dicruridae & Dicrurus caerulescens & White-bellied drongo & $\mathrm{LC}$ \\
\hline Dicaeidae & Dicaeum erythrorhynchos & Pale billed flower pecker & $\mathrm{LC}$ \\
\hline \multirow[t]{3}{*}{ Estrildidae } & Lonchura punctulate & Scaly Breasted Munia & $\mathrm{LC}$ \\
\hline & Lonchura striata & White rumped munia & LC \\
\hline & Lonchura malacca & Tricoloured munia & $\mathrm{LC}$ \\
\hline \multirow[t]{2}{*}{ Hirundinidae } & Cecropis daurica & Red rumped swallow & En/ LC \\
\hline & Hirundo rustica & Barn swallow & $\mathrm{M} / \mathrm{LC}$ \\
\hline
\end{tabular}

Sri Lankan Journal of Agriculture and Ecosystems, 3(1): p-p, 2021 
Table 1. Checklist of birds recorded during the study in five wetlands.

\begin{tabular}{|c|c|c|c|}
\hline Family & Scientific Name & Common Name & $\begin{array}{l}\text { National Conservation } \\
\text { Status (Goonatilake, } \\
2020 \text { ) }\end{array}$ \\
\hline & Cypsiurus balasiensis & Palm swift & LC \\
\hline \multirow[t]{2}{*}{ Nectariniidae } & Nectarinia zeylonica & Purple rumped sunbird & LC \\
\hline & Nectarinia lotenia & Long billed sunbird & $\mathrm{LC}$ \\
\hline Oriolidae & Oriolus xanthornus & Black hooded oriole & LC \\
\hline \multirow{2}{*}{ Muscicapida } & Copsychus saularis & Oriental magpie robin & $\mathrm{LC}$ \\
\hline & Saxicoloides fulicatus & Indian robin & $\mathrm{LC}$ \\
\hline Picidae & Dinopium benghalense & Black-rumped flame back & $\mathrm{En} / \mathrm{LC}$ \\
\hline Psittacidae & Psittacula krameri & Rose-ringed parakeet & $\mathrm{LC}$ \\
\hline \multirow[t]{2}{*}{ Pycnonotidae } & Pycnonotus cafer & Red-vented bulbul & $\mathrm{LC}$ \\
\hline & Pycnonotus luteolus & White browed bulbul & $\mathrm{LC}$ \\
\hline Ramphastidae & Megalaima zeylanica & Brown-headed barbet & $\mathrm{LC}$ \\
\hline \multirow[t]{3}{*}{ Sturnidae } & Acridotheres tristis & Common myna & $\mathrm{LC}$ \\
\hline & Gracula religiosa & Hill myna & $\mathrm{LC}$ \\
\hline & Pastor roseus & Rosy starling & M/LC \\
\hline Meropidae & Merops philippinus & Blue tailed bee eater & M/LC \\
\hline Sylviidae & Orthotomus sutorius & Common tailorbird & $\mathrm{LC}$ \\
\hline Timaliidae & Turdoides affinis & Yellow billed babbler & $\mathrm{LC}$ \\
\hline Laridae & Chlidonias hybrid & Whiskered tern* & M/LC \\
\hline Pelecanidae & Pelecanus philippensis & Spot-billed pelican* & NT \\
\hline \multirow[t]{4}{*}{ Rallidae } & Amaurornis phoenicurus & White-breasted water hen* & LC \\
\hline & Porzana fusca & Ruddy breasted crake* & NT \\
\hline & Porphyrio porphyrio & Purple swamp hen* & $\mathrm{LC}$ \\
\hline & Gallinula chloropus & Common moorhen* & $\mathrm{LC}$ \\
\hline Podicipedidae & Tachybaptus ruficollis & Little grebe* & $\mathrm{LC}$ \\
\hline \multirow[t]{2}{*}{ Anatidae } & Nettapus coromandelianus & Cotton teal* & $\mathrm{LC}$ \\
\hline & Dendrocygna javanica & Lesser whistling duck* & $\mathrm{LC}$ \\
\hline \multirow[t]{2}{*}{ Phalacrocoracidae } & Phalacrocorax fuscicollis & Indian cormorant* & $\mathrm{LC}$ \\
\hline & Microcarbo niger & Little cormorant* & $\mathrm{LC}$ \\
\hline
\end{tabular}


Table 1. Checklist of birds recorded during the study in five wetlands.

\begin{tabular}{|c|c|c|c|}
\hline Family & Scientific Name & Common Name & $\begin{array}{l}\text { National Conservation } \\
\text { Status (Goonatilake, } \\
2020 \text { ) }\end{array}$ \\
\hline Anhingidae & Anhinga melanogaster & Oriental darter* & NT \\
\hline \multirow[t]{5}{*}{ Ardeidae } & Egretta garzetta & Little egret* & $\mathrm{LC}$ \\
\hline & Ardea intermedia & Intermediate egret* & $\mathrm{LC}$ \\
\hline & Ardea alba & Great egret* & LC \\
\hline & Ardeola grayii & Indian pond heron* & $\mathrm{LC}$ \\
\hline & Butorides striata & Striated heron* & $\mathrm{LC}$ \\
\hline Threskiornithidae & Threskiornis melanocephalus & Black headed ibis* & NT \\
\hline \multirow[t]{2}{*}{ Ciconiidae } & Mycteria leucocephala & Painted stork* & NT \\
\hline & Anastomus oscitans & Asian open bill* & $\mathrm{LC}$ \\
\hline \multirow[t]{2}{*}{ Ardeidae } & Ardea purpurea & Purple heron* & $\mathrm{LC}$ \\
\hline & Ardea cinerea & Grey heron* & $\mathrm{LC}$ \\
\hline
\end{tabular}

LC-Least Concern; NT- Near threatened; M-Migrants; *- birds considered as aquatic birds for the analysis

Table 2. Shannon-Wiener diversity index (H); bird density (BD); species richness (SR); $( \pm$ SE) and water quality parameters $( \pm$ SE) in five wetlands studied. Abbreviations of the wetlands are given in Fig. 2.

\begin{tabular}{|c|c|c|c|c|c|c|c|c|c|c|}
\hline Wetland & $\mathrm{H}^{\prime}$ & BD (Birds $/ \mathrm{km}^{2}$ ) & SR & $\mathrm{T}\left({ }^{\circ} \mathrm{C}\right)$ & DO (mg/L) & $\mathrm{pH}$ & SL (PSU) & $\mathrm{EC}(\mu \mathrm{S} / \mathrm{cm})$ & TDS (mg/L) & SDD (m) \\
\hline BG & $1.04 \pm 0.04$ & $2208.06 \pm 130.1$ & $17.91 \pm 0.66$ & $29.91 \pm 0.30$ & $3.31 \pm 0.33$ & $6.16 \pm 0.23$ & $0.214 \pm 0.03$ & $444.13 \pm 69.2$ & $215.5 \pm 31.69$ & $0.97 \pm 0.11$ \\
\hline DS & $0.99 \pm 0.05$ & $2521.47 \pm 179.2$ & $17.17 \pm 0.61$ & $30.37 \pm 0.10$ & $0.28 \pm 0.28$ & $5.89 \pm 0.2$ & $0.157 \pm 0.01$ & $321.57 \pm 32.1$ & $162.6 \pm 17.77$ & $0.47 \pm 0.04$ \\
\hline $\mathrm{HE}$ & $1.23 \pm 0.06$ & $1677.45 \pm 137.2$ & $15.16 \pm 0.38$ & $29.7 \pm 0.20$ & $6.93 \pm 0.07$ & $5.99 \pm 0.15$ & $0.14 \pm 0.009$ & $241.77 \pm 19.7$ & $158.0 \pm 5.5$ & $0.79 \pm 0.04$ \\
\hline KG & $1.17 \pm 0.04$ & $1860.02 \pm 121.2$ & $14.85 \pm 0.36$ & $29.66 \pm 0.25$ & $3.54 \pm 0.44$ & $7.54 \pm 0.07$ & $0.21 \pm 0.002$ & $208.76 \pm 61.7$ & $213.0 \pm 19.17$ & $0.55 \pm 0.02$ \\
\hline TL & $1.71 \pm 0.03$ & $4990.09 \pm 151.3$ & $22.07 \pm 0.68$ & $30.15 \pm 0.21$ & $7.13 \pm 0.11$ & $6.74 \pm 0.21$ & $0.068 \pm 0.01$ & $209.06 \pm 7.1$ & $103.01 \pm 33.58$ & $1.27 \pm 0.04$ \\
\hline
\end{tabular}

Abbreviations: T-Temperature, DO- Dissolved Oxygen, SL-Salinity, EC- Electron Conductivity, TDS-Total dissolved Solid, SDD- Secchi Disc Depth 
Highest dissolved oxygen level (DO) and Secchi disk depth (SDD) were observed in Thalangama Tank and they were $7.13 \pm 0.11$ $\mathrm{mgL}^{-1}$ and $1.27 \pm 0.04 \mathrm{~m}$ respectively. The D0 and SDD in Thalangama Tank showed a significant difference with Beddagana and Diyasaru $(p<0.01)$. The higher DO level of water is probably due to sufficient aquatic vegetation and less load of organic pollutants. This may have resulted in less microbial activities and less utilization of DO in water. The highest total dissolved solids (TDS) were observed in Beddagana wetland $(215 \pm 31.69 \mathrm{mg} / \mathrm{L}), \quad$ followed by Kiribathgoda wetland $\left(213 \pm 19.17 \mathrm{mgL}^{-1}\right)$ and dropped further to Thalangama Tank (103.01 $\pm 33.58 \mathrm{mg} / \mathrm{L})$ (Table. 3). The reason for high accumulations of TDS probably due to the accumulation of sewage from adjacent human dwellings (personnel observations by authors). Temperature (29.66 \pm 0.25 $\left.30.37 \pm 0.10^{\circ} \mathrm{C}\right)$ and $\mathrm{pH}(5.89 \pm 0.2-7.54 \pm 0.07)$ among the wetlands were varied in short range. Maximum EC was noted in Beddagana Wetland Park $\left(444.13 \pm 69.2 \mu \mathrm{Scm}^{-1}\right)$ and was lowest in Kiribathgoda wetland $\left(208.76 \pm 61.7 \mu \mathrm{Scm}^{-1}\right)$. The lowest salinity (SL) was observed in Thalangama Tank (0.068 $\pm 0.01 \mathrm{PSU})$, while the maximum was recorded in Beddagana Wetland Park (0.214 \pm 0.03 PSU) (Table 2).
Shannon- Wiener species diversity index $\left(\mathrm{H}^{\prime}\right)$ positively correlated with SDD (Fig. 3A) and DO of water (Fig. 3B). TDS, EC, and salinity were main physical parameters which affect the bird population indices of wetlands. Shannon- Wiener species diversity index $\left(\mathrm{H}^{\prime}\right)$ had significant negative relationships with TDS (Fig. 3C) and salinity (Fig. 3E). Bird density among the five wetlands studied was positively correlated with SDD and Temperature ( $p>0.05)$ (Fig. 4A and 4B). Moreover, bird density was negatively correlated with salinity (Fig. 4C) and TDS (Fig. 4D). When the correlation was carried out between the physical and chemical parameters with the species richness, a significant positive correlation was established between the species richness and SDD (Fig. 4E). Species richness was negatively correlated with TDS (Fig. 4G) and salinity (Fig. 4H). Therefore, these factors (e.g., TDS, Salinity, SDD and DO) can be considered as the limiting factors for the bird distribution and in addition to distribution of the aquatic organisms that are directly consumed by aquatic birds (Balasubramanian and Kannan 2005; Sridhar et al. 2006). Hence, it can be suggested that there is a possible relationship between measured water quality parameters and abundance of bird's prey items in the wetland waters. 
According to Baldassarre and Arengo (2000), availability of food was high in both low salinity ponds (0.063-0.073 PSU) and high salinity ponds (0.078-0.136 PSU), where less food was found in intermediate salinity ponds. In the present study, the salinity ranged from 0.068-0.214 PSU suggesting current results approximately confirm the above finding through polynomial regression relationship between salinity and bird diversity (Fig. 3E), density (Fig. 4C), and richness (Fig. $4 \mathrm{H})$.

Further, there are diverse forms of dissolved solids in nature and in addition to the natural sources of input, sewage also can be considered as a most important source of dissolved solids (Borges 2002). Transparency or the amount of light, which penetrates is considered a factor that fluctuates according to seasons. Water transparency strongly depends on the dissolved solids in the water (http://water.epa.gov). Timms and Midgley, (1970) have revealed an inverse relationship in between transparency and suspended sediment load. The rain-water can bring large amounts of dissolved and suspended inorganic and organic materials from upper catchment areas as well as from lower floodplains during the rainy season making the water to be more turbid. This causes a reduction in water transparency and high turbidity highlight the habitat unsuitability for the aquatic lives. That makes a direct impact on abundance of aquatic birds, as aquatic organisms are their major food sources. In the present study, highest TDS was recorded in Beddagana Wetland Park. In Kiribathgoda wetland, soil erosion and industrial effluents may be the major concerning factors for the high amount of TDS. Even though the temperature and $\mathrm{pH}$ in a water body play a significant role as a regulatory factor for both biological activities and the physical and chemical characters of the ecosystem (Sonal et al. 2010), present study was not able to record significant relationships between population parameters of aquatic birds and $\mathrm{pH}$ or temperature (Fig. 4B;4F). Temperature and $\mathrm{pH}$ of the water body is affected by several factors such as basin altitude, morphology, vegetation, and topography (You et al. 2019). In the present study, all those factors can be considered similar in all studied wetlands. That can be the main reason to detect a short range of water temperature $(29.66 \pm 0.25 \quad$ $\left.30.37 \pm 0.10 \quad{ }^{\circ} \mathrm{C}\right)$ and $\mathrm{pH} \quad(5.89 \pm 0.2$ 7.54 \pm 0.07 ) (Table 2). It is observed that, there was a high accumulation of electrolytes runoff thus, higher EC in Beddagana and Diyasaru Parks (Table 2). It 
is revealed the population parameters of aquatic birds at the Diyasaru and Beddagana Wetland Parks were simultaneously influenced by the EC. The closest reason could be the effluent from
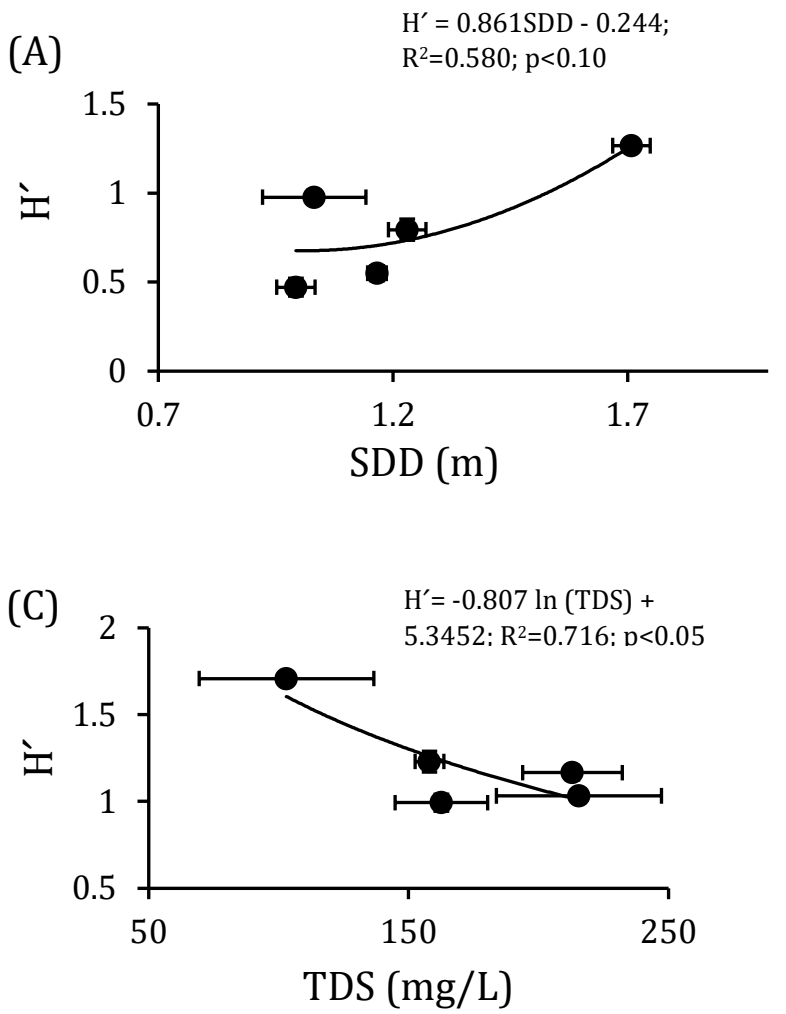

industries and households of the vicinity. Though there were no strong evidence, agricultural chemicals could also be added to these waters from the plenty of commercial plant nurseries in vicinity.
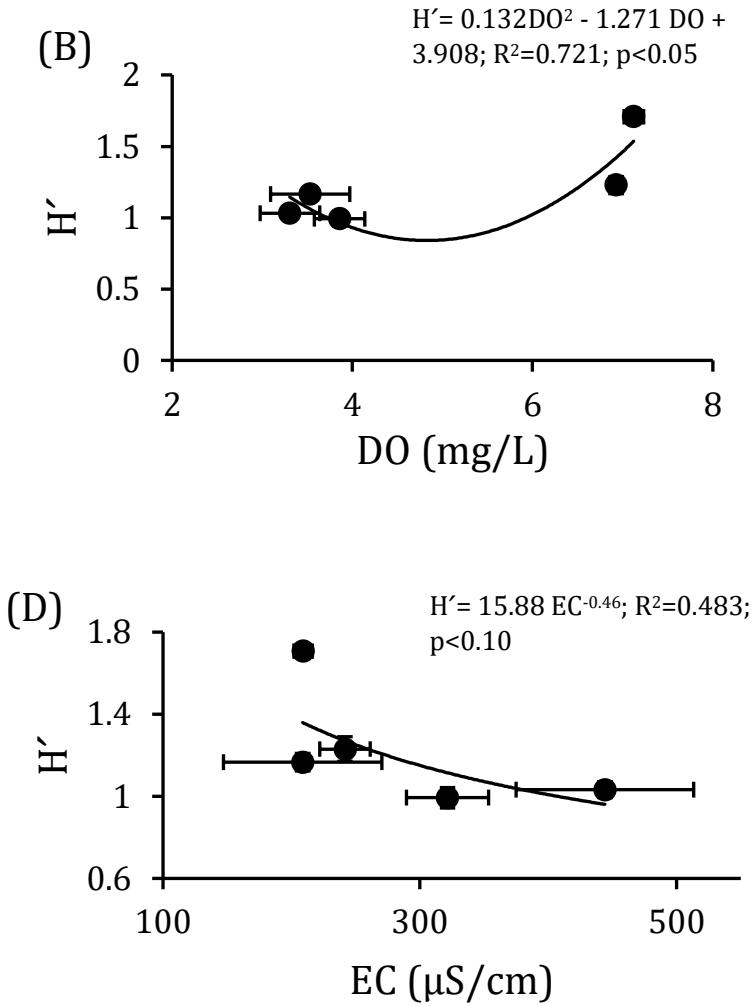

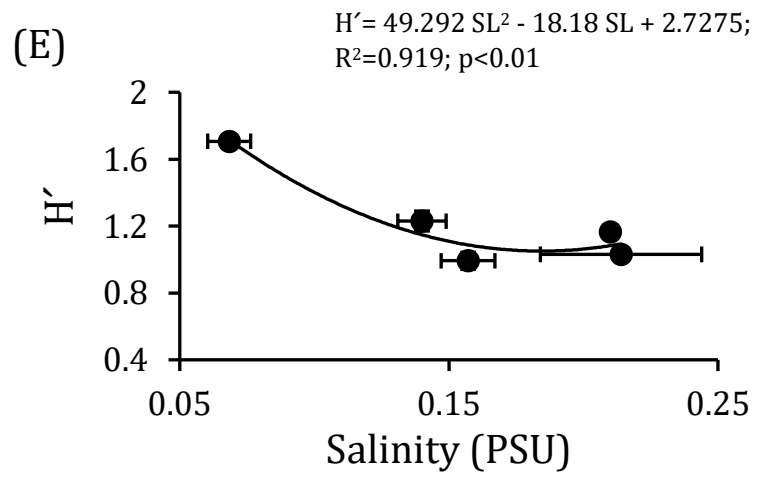

Figure 3. Regression relationships of Shannon-Wiener diversity index (H) with (A) Secchi Disk Depth (SDD); (B) Dissolved Oxygen (DO);(C) Total Dissolved Solids (TDS); (D) Electron Conductivity (EC); (E) Salinity (SL) in five wetlands studied. Regression equations, significant levels and correlation co-efficient $\left(\mathrm{R}^{2}\right)$ values of the estimated relationships are also given 

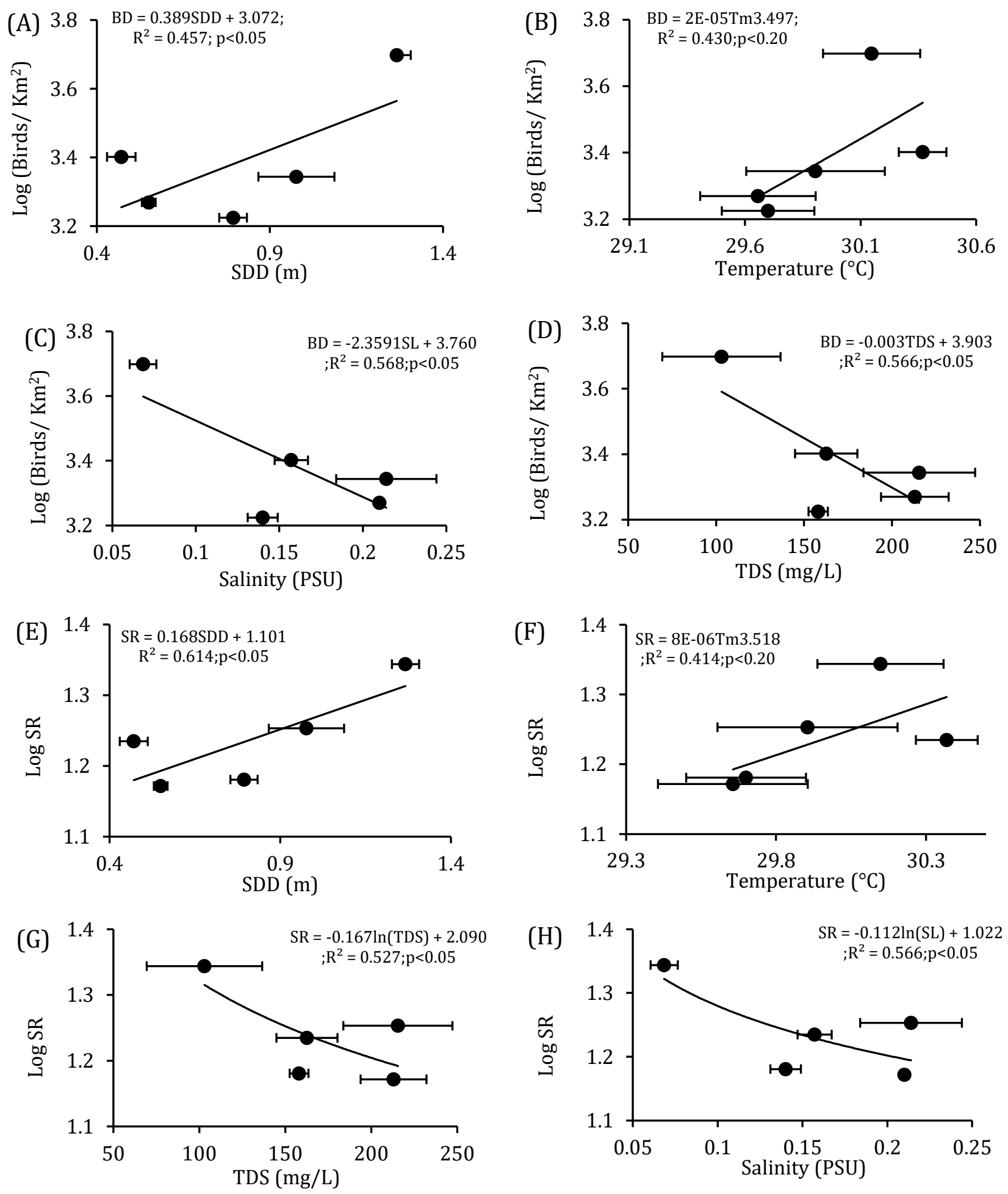

Figure 4. Regression relationships of log bird density (BD) with (A) Secchi Disk Depth (SDD); (B) Temperature ( $\mathrm{T}_{\mathrm{m}}$ ); (C) Salinity (SL); (D) Total Dissolved Solids (TDS) in five wetlands studied and the regression relationships of log species richness (SR) with (E) Secchi Disk Depth (SDD); (F) Temperature ( $\mathrm{T}_{\mathrm{m}}$ ); (G) Total Dissolved Solids (TDS); (H) Salinity (SL) in five wetlands studied. Regression equations, correlation co-efficient $\left(\mathrm{R}^{2}\right)$ and significant levels of the estimated relationships are also given. 
Correlation coefficients showed a weak correlation pattern comparing with regression relationships obtained only for aquatic birds (Table 3). Therefore, these results suggest that there was a substantial effect of water quality towards the aquatic birds than the wetland associate terrestrial birds.
PC 1 score and correlation of three measured population parameters are also explained in Fig. 5 B-5D. Bird population parameters have (e.g. diversity, density and species richness) negatively correlated with PC 1 scores (Fig. 5B, 5C and 5D). Negative PC 1 scores were denoted by SDD and DO.

Table 3. Pearson's correlation coefficients calculated for both terrestrial and aquatic birds together. Significant levels are also given.

\begin{tabular}{llllllll}
\hline & $\mathrm{T} m$ & $\mathrm{DO}$ & $\mathrm{pH}$ & $\mathrm{SL}$ & $\mathrm{EC}$ & $\mathrm{TDS}$ & $\mathrm{SDD}$ \\
\hline $\mathrm{H}$ & -0.25 & $0.43^{*}$ & 0.24 & -0.33 & -0.02 & -0.26 & $0.94^{* * *}$ \\
$\mathrm{BD}$ & $0.68^{*}$ & 0.14 & -0.04 & $-0.52^{*}$ & 0.17 & $-0.52^{*}$ & $0.68^{*}$ \\
$\mathrm{SR}$ & $0.52^{*}$ & -0.01 & -0.28 & -0.24 & $0.57^{*}$ & -0.23 & $0.70^{* *}$ \\
\hline
\end{tabular}

Significant levels $=p<0.2^{*} ; p<0.1^{* *} ; p<0.001^{* * *}$

Results of the Principal component analysis (PCA) which was performed to find out the physical and chemical parameters that influenced the variation of bird population parameters are shown in Fig. 5A. Eigenvalues of PCA 1 explain the $50.5 \%$ variance (Table 4).

Table 4. Eigen values and variance explain by the principal component analysis

\begin{tabular}{lll}
\hline PC & Eigenvalue & \% variance \\
\hline 1 & 3.54 & 50.5 \\
2 & 1.91 & 27.3 \\
3 & 0.96 & 13.7 \\
4 & 0.60 & 8.6 \\
\hline
\end{tabular}

Hence, SDD and DO were extremely influenced on Thalangama Tank followed by Heen Ela marsh (Fig. 5A). For the sites of Beddagana and Kiribathgoda, salinity and TDS were the extremely influencing physical and chemical parameters. Other than these factors, Beddagana had an influence from EC (Fig. 5A). Further, Diyasaru Park had an effect from EC on the variation of diversity, density and species richness of the water birds (Fig. 5A) 

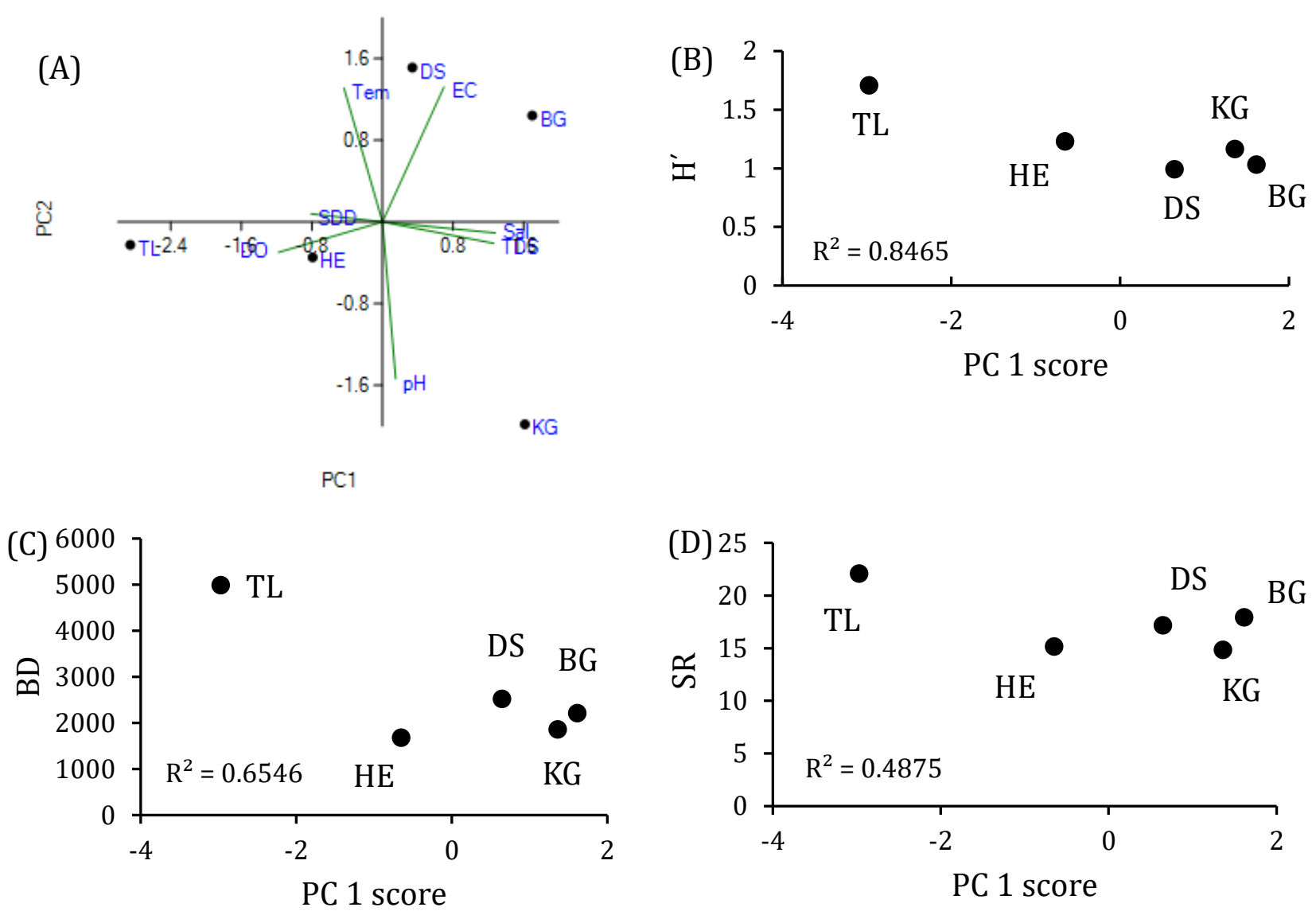

Figure 5. Results of Principal Component Analysis. (A) PCA plot of physical and chemical parameters of water in the studied wetlands. PC 1 score (driven by mainly SDD and DO) and correlation of three measured population parameters (B) Shannon-Wiener diversity index; (C) Bird density and (D) Species richness

The overall species diversity, richness and density were higher in Thalangama Tank wetland system. It was evident that particularly less turbidity and high DO levels in water which create a suitable habitat for fish (Steinberger and Wohl 2003) and macro invertebrates (Van de Meutter et al. 2005). In the present study, DO level ranged between $0.28 \pm 0.28 \quad-7.13 \pm 0.11 \mathrm{mgL}^{-1}$ (Table. 2). Manahan (1993) described the high level of DO in water is resulted due less organic matter and industrial waste present in a waterbody. A low DO level of the water body indicates the stress problems for aquatic organisms and if DO level is high or close to saturation $\left(7 \mathrm{mgL}^{-1}\right.$, it is considered a healthy lotic ecosystem (Manahan, 1993). Among the multiple limiting factors in wetlands, DO levels are considered prominent due to the larger effects it could have on chemical and biological processes of the system (Heimann and Femmer, 1998). Therefore, reduced oxygen level in the water has a direct impact on the biotic community of water body while also being a threat to waters' self-purification capacity. These low values of DO indicate the presence of 
untreated waste in Diyasaru Park, Beddagana Park and Kiribathgoda wetlands. Fish and other invertebrates act as the main food sources for aquatic birds and a positive correlation can be observed between abundance of fish and abundance of birds (Labe et al. 2018). Those trophic relationships are predominantly important for the bird population, and it could be a stout reason for the observed high species richness in Thalangama Tank. Wetland Management Strategy (2016) has recorded the highest freshwater fish and amphibian diversity in Thalangama Tank system and those could be the main food items for aquatic birds. Beddagana Wetland Park and Diyasaru Park are maintaining as wetland parks and were formerly degraded lands due to various anthropogenic activities which are now being recovered. Some species such as Porzana fusca, Pastor roseus and Aegithina tiphia were recorded only in Diyasaru Park. The determination of bird congregation can be done considering the area of open water as an important factor (González et al. 2009). The quality of water in smaller water bodies can significantly change along with amount of migratory birds due to the addition of extra loads of nutrients (Andrikovics et al. 2003). Thalangama Tank is comparatively a large open water body when compared with other areas and therefore sudden fluctuations of water quality may be less frequent. This can be another reason to have favorable physical and chemical parameters in Thalangama Tank.

The present study revealed multiple factors which could threaten both the wetland ecosystem and its bird population since birds utilize wetland ecosystem for feeding, shelter and other social interactions. Several local wetlands are seriously threatened with the declining of local bird population. Unplanned economic development, solid waste dumping and illegal encroachments could be some major reasons which bring water birds in danger. Pollution through industrial and household effluents is also a major threat to the birds in this aquatic ecosystem (Elizabeth 2000; Mahaulpatha et al. 2008). Based on the diversity, richness and species density, high priority efforts should be dedicated for the conservation of Thalangama Tank wetland system, due to comprising of a high bird diversity being popularized with many local and foreign birds. Since Diyasaru Park and Beddagana Wetland Park are maintaining as public parks, the habitats and their conservation have already been assured. During the dry season some of the major ponds in Beddagana Wetland Park get dried-off. Therefore, such an extreme level 
of disturbance may also influence the reduction of bird diversity. Heen Ela area is currently undergoing a rapid development. The conservation priorities should be subsequently adopted to Heen Ela for the long-term survival of aquatic birds. Identifying sources of pollution is particularly important for the future conservation of aquatic birds. In order to bring the conservational efforts to reality, it is very important to reduce the anthropogenic disturbances for the wetland eco systems (Bobbink et al. 2016; Aronson et al. 2017). Even though the interrelationship between human and wetlands can bring many economic advantages, it will ultimately increase the challenge of protecting different threatened and vulnerable wetlands and associate avian species.

\section{Conclusion}

Similar to many tropical countries, the urban wetlands in Sri Lanka are diminishing at an alarming rate. Wetlands act as the prime habitats for aquatic birds, and in this study the distribution of the bird species was scattered throughout the five wetlands. Transparency and high dissolved oxygen levels in the waters enhance the species diversity and richness. Conversely, high electrical conductivity, salinity and total dissolve solids decrease the species diversity and richness of these avifauna. Apart from these factors, water temperature was an influential factor to regulate the density and richness of aquatic birds. Current study revealed that the bird population parameters were influenced by multiple physical and chemical parameters. Water transparency and dissolved oxygen levels were extremely influencing on Thalangama Tank followed by Heen Ela marsh. For the sites of Beddagana and Kiribathgoda, salinity and total dissolved solids were the extremely influencing physical and chemical parameters. Similarly, Beddagana and Diyasaru Park had a great effect from electrical conductivity on the variation of diversity, density and species richness of the water birds. Therefore, the present study has shown that variations in water quality parameters are directly affecting the distribution and diversity of aquatic birds in urban wetlands.

Conflicts of interest: The authors have no conflicts of interest regarding this publication.

\section{References}

Andrikovics S, Gare G, Juhasz J, Lakatos G (2003) Mallard population parameters and their effect on water quality. Proceedings of the $4^{\text {th }}$ Conference: Aquatic Birds Working 
Group of Societas Internationalis Limnologiae (SIL), Sackville, Canada. pp 1516.

Aronson M F, Christopher A L, Karl L E, Mark A G, Susannah B L, Scott M, Charles H N, Timothy V (2017) Biodiversity in the city: key challenges for urban green space management. Frontiers in Ecology and the Environment, 15: pp 189-196.

Balasubramanian R, Kannan L (2005) Physico-chemical characteristics of the coral reef environs of the Gulf of Mannar biosphere reserve, India. International Journal of Ecology and Environment Science, 31: pp 265-271.

Baldassarre G A, Arengo F (2000) A review of the ecology and conservation of Caribbean Flamingos in Yucaton, Mexico. Waterbirds, 23: pp 70-79.

Bibby C J, Bugress N D, Hill D (1992) Bird census techniques. Massachusetts: Academic Press Limited, pp 78-85.

Bobbink R, Whigham D F, Beltman B, Verhoeven J T A (2016) Wetland Functioning in Relation to Biodiversity Conservation and Restoration, Ecological studies, 191: pp 17-25.
Borges S D (2002) Studies on the ecology of wader birds in the Mandovi estuary of Goa, India. Ph.D. Thesis, Goa Uni-versity, Goa.

Cherry J A (2011) Ecology of wetland ecosystems: water, substrate and life. Nature Education Knowledge, 3: pp 1-16.

Clarke K R, Warwick R M (2001) Change in marine communities: an approach to statistical analyses and interpretation, PRIMER-E, Plymouth, pp 258.

Climate-data.org (2021) climate data for cities worldwide. Available on: https://en.climate-data.org. Retrieved on: 12 May 2021.

Elizabeth P (2000) The impact of anthropogenic factors on urban wetlands: case of Msimbazi valley Dar-es-Salaam. Geography, pp 58-69.

Environmental Protection Agency (2012) Turbidity. In Water: Monitoring \& Assessment; Available on: http://water. epa.gov/type/rsl/monitoring/vms55.cfm. Retrieved on: 12 May 2021.

González A L, Victoriano P F, Schlatter R (2009) Waterbird Assemblages and Habitat Characteristics in Wetlands: Influence of 
Temporal Variability on Species-Habitat Relationships. Waterbirds, pp 32.

Goonatilake S (2020) Checklist of the Selected Faunal groups in Sri Lanka - IUCN Data base. IUCN Sri Lanka country office, Colombo.

Green A J (2014) Ecosystem Services Provided by Waterbirds, Biological Reviews, 15: pp 65-76.

Harrison J, Worfolk T A (1999) Guide to the Birds of Sri Lanka, Oxford University Press, pp 219.

Heimann D C, Femmer S R. (1995) Water quality, hydrology and invertebrate communities of three remnant wetlands in Missouri, pp 97.

IUCN Sri Lanka and Central Environmental Authority (2006) National Wetland Directory of Sri Lanka, Colombo, Sri Lanka.

Keten A, Sarcan E, Anderson J T (2020) Temporal Patterns of Wetland-Associated Bird Assemblages in Altered Wetlands in Turkey. Polish Journal of Ecology, 67(4): pp 316-320.
Kotagama S, Ratnavira G (2017) An Illustrated Guide to the Birds of Sri Lanka. Field Ornithology Group of Sri Lanka, University of Colombo, Colombo, pp 356.

Kotagama S W, Bambaradeniya C N B (2006) An Overview of the Wetlands of Sri Lanka and their Conservation Significance. In IUCN Sri Lanka and the Central Environmental Authority, National Wetland Directory of Sri Lanka, Colombo, Sri Lanka.

Krebs C J (1999) Ecological Methodology (2nd edition) Addison-Welsey Educational Publishers, Inc., USA, pp 620.

Labe T E, Iwar I M, Uloko I J (2018) Species diversity and abundance of avifauna in the University of Agriculture, Benue state, north central Nigeria. Forestry research and Engineering: International Journal, 2(4): pp 198-202.

Maat S M (2015) Exploring Engineering Technology Students' Perception in Learning Statistics Using Minitab Mediterranean Journal of Social Sciences, pp $6: 3$.

Mahaulpatha W A D, Mahaulpatha W M T, Wasantha K A I (2008) Effect of Water level and Invasive Plants on Pheasant - tailed 
Jacana (Tlydrophasianus chirugus) at the Anawilundawa Ramsar Site of NorthWestern of Sri Lanka. Wetland Ecology Management, 16: pp 33-42.

Manahan S E (1993) Fundamentals of environmental chemistry ( $6^{\text {th }}$ Edition) Lewis publishers, Georgia, pp 844.

Mitsch W J, Gosselink J G (2000) Wetlands ( $3^{\text {rd }}$ edition) John Wiley, New York.

Murray C G, Kasel S, Loyn R H, Hepworth G, Hamilton A J (2013) Waterbirds' use of artificial wetlands in an Australian urban landscape. Hydrobiologia, 716: pp 131-146.

Osborn P L (2000) Tropical Ecosystems and Ecological Concepts, Cambridge University Press, pp 464.

Paracuellos M (2006) How can habitat selection affect the use of a wetland complex by waterbirds? Biodiversity and Conservation, 15: pp 4569-4582.

Rameshkumar S, Radhakrishnan K, Aanand S, Rajaram R (2016) Influence of physicochemical water quality on aquatic macrophyte diversity in seasonal wetlands. Applied Water Science, pp 9:12.
Ramsar (2021) Available on: https://www.ramsar.org/wetland/srilanka. Retrieved on: 12 May 2021

Rodger W A, Panwar H S (1990) Planning a Wildlife Protected Network in India, 2 Volume project PO: IND/82/003, FAO, and Dehradun, pp 120.

Shannon C E, Weaver W (1949) The Mathematical Theory of Communication. University of Illions Press, Urbana, USA.

Sonal D, Jagruti R, Geeta P (2010) Avifaunal diversity and water quality analysis of an inland wetland. Journal of Wetlands Ecology, 4: pp 1-32.

Sridhar R, Thangaradjou T, Kumar S (2006) Water quality and phytoplankton characteristics in the Palk Bay, southeast coast of India. Journal of Environmental Biology, 27: pp 561-566.

Steinberger N, Wohl E (2003) Impacts to water quality and fish habitat associated with maintaining natural channels for flood control. Environmental Management, 31(6): pp 724-40.

Stewart R E (2007) Technical aspects of wetlands: Wetlands as bird habitat. United 
States Geological Survey Water Supply Paper, pp 24-25.

Timms B V, Midgly S H (1970) The limnology of Borumba dam, Queensland. Proceedings Royal Society of South Africa, 3(2): pp 37-41.

Van de Meutter F, Stoks R, De Meester L (2005) The effect of turbidity state and microhabitat on macroinvertebrate assemblages: a pilot study of six shallow lakes. In: Segers H., Martens K. (eds) Aquatic Biodiversity II. Developments in Hydrobiology, 180: pp 954-1020.
Vijayan V S (1991) Keoladeo National Park Ecology Study: Summary Report 19801990. Bombay Natural History Society, Mumbai. pp 57.

Wetland management strategy (2016) Metro Colombo urban development project.

You Q, Fang N, Liu L, Yang W, Zhang L, Wang Y (2019) Effects of land use, topography, climate and socio-economic factors on geographical variation pattern of inland surface water quality in China. PLoS ONE, 14(6): pp 8-11. 